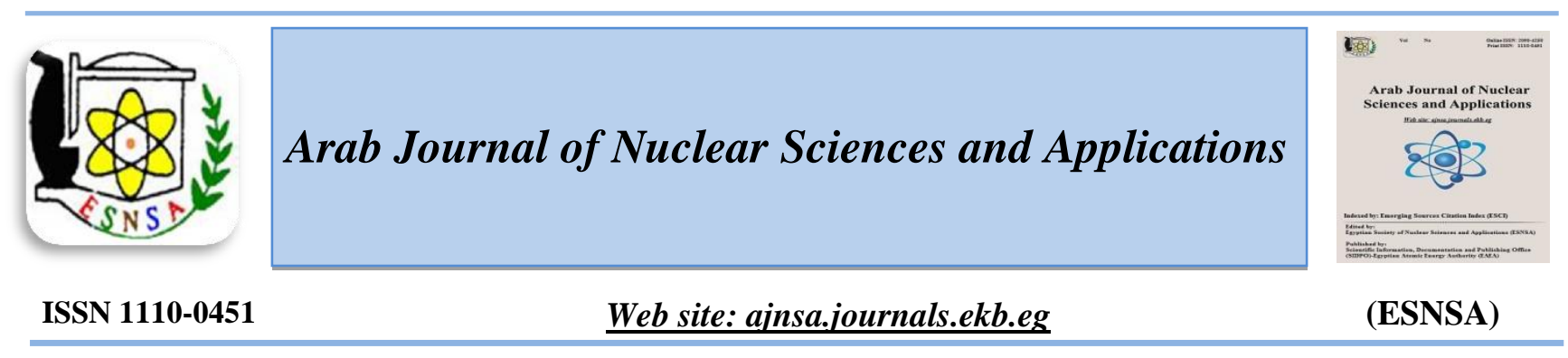

\title{
Radiological Hazards of TENORM Contaminated Soil at Oil and Gas Fields
}

\author{
YA.A. Ahmed ${ }^{(1)}$, R.M.M. Mahmoud ${ }^{(1)}$, M.R. Ezz El-Din ${ }^{(1)}$ and Mostafa M. H. Khalil $^{(2)}$ \\ ${ }^{I}$ Nuclear and Radiological Regulatory Authority, Cairo, Egypt \\ ${ }^{2}$ Faculty of Science - Ain Shams University, Cairo, Egypt
}

Received $17^{\text {th }}$ Sept. 2018

Accepted $17^{\text {th }}$ Oct. 2018

\begin{abstract}
The presence of large quantities of TENORM contaminated soil produced during the extraction and processing of crude oil at oil extraction sites exceeds the radiological reference levels assigned by the international organizations [1] TENORM may cause the exposure of workers at these sites to unusual radiation hazards. This is of a great importance for assessing the dose to the workers at these sites, which plays a vital rule in exploring the radiation health risks due to radiation exposure. This study aims to assess the TENORM activity concentration of the contaminated soil in some oil and gas production fields in Egypt. The assessment of the radiological hazards for the workers by estimating the annual doses and the radiation hazard indices were also studied. The obtained data show that the activity concentration of ${ }^{238} \mathrm{U},{ }^{232} \mathrm{Th}$ and ${ }^{40} \mathrm{~K}$ ranged from 166 to $42567 \mathrm{~Bq} / \mathrm{Kg}, 88$ to $8358 \mathrm{~Bq} / \mathrm{Kg}$ and 52.22 to 440 $\mathrm{Bq} / \mathrm{Kg}$ respectively. The calculated absorbed dose rate ranged from $132.39-24732.67 \mathrm{nGy} / \mathrm{h}$, and the calculated Annual Effective Dose Equivalent ranged from 0.16 - 30.33 $\mathrm{mSv} / \mathrm{y}$ (depending on the activity concentration of NORM contamination). The radiation hazard indices were calculated and found to be much higher than the international values. From the obtained results, it has been concluded that the remediation/decontamination of the contaminated soils in the production sites that have activity concentration higher than $400 \mathrm{~Bq} / \mathrm{Kg}$ is highly recommended. In addition, Egyptian regulations should be coherent to force companies to decontaminate NORM contamination to reduce as much as possible the radiation worker exposure.
\end{abstract}

Keywords: NORM activity concentration, Dose assessment, Radiation hazardous indices

\section{Introduction}

In recent decades, the development of new technologies in oil production fields has resulted in the generation of by-products and waste called technologically enhanced naturally occurring radioactive materials (TENORM) produced from several industries such as uranium mining, coal ash, phosphate ore processing, metal mining and processing, and petroleum industry [2-3]. Therefore, human technical activity can increase radiation exposure, not only to the person directly involved in these activities, but also to the local or even whole population and environment. The majority of radionuclides in TENORM are $\mathrm{U}, \mathrm{Th}$ and their respective decay progenies. Usually, radium $\left({ }^{226} \mathrm{Ra}\right)$ and radon $\left({ }^{222} \mathrm{Rn}\right)$ are used to characterize the redistribution of TENORM that results from human activities [3-4]. In oil and gas production, the arising TENORM may be solid waste (scale and/or sludge) or produced waters [5]. The activity concentrations of ${ }^{226} \mathrm{Ra}$ in TENORM can be much higher than the exemption levels established by IAEA [6]. The recommended exemption level for uranium series is ${ }^{238} \mathrm{U}=1 \mathrm{~Bq} / \mathrm{g}$ and ${ }^{226} \mathrm{Ra}=10 \mathrm{~Bq} / \mathrm{g}$, while for thorium decay a chain is ${ }^{232} \mathrm{Th}=1 \mathrm{~Bq} / \mathrm{g},{ }^{228} \mathrm{Ra}=10 \mathrm{~Bq} / \mathrm{g}$ and ${ }^{224} \mathrm{Ra}=$ $10 \mathrm{~Bq} / \mathrm{g}$ [5]. The initial evaluations of occupational radiation exposure in the oil and gas industries were reported a few decades ago [7].

The presence of radium-226 at high concentrations in radioactive wastes that resulted from oil and gas

Corresponding author: yassernasef@yahoo.com

DOI: $10.21608 / a j n s a .2019 .5150 .1119$.

(C) Scientific Information, Documentation and Publishing Office (SIDPO)-EAEA 
industries is a serious issue harmfully affects the human health and environment due to its toxicity and long half-life (1620 years). Levels of activity in the oil-produced water can attain several hundred Becquerels per liter, depending on the source rocks of the oil reservoirs and the associated brine water [8-9]. Discharging these types of wastewater into the environment causes environmental pollution as surface and ground waters as well as in soil, and thus exposure to the public and the workers [10].

During routine operations, workers in oil and gas fields are exposed to external gamma radiation. This external gamma radiation exposure is due to radioactive species precipitated at walls of pipes and vessels as well as that arising from TENORM contaminated soil. The dose rate at oil and gas fields could be in order of tens of micro Sievert per hour.

This study aims to assess the radiological hazard indices for some oil and gas fields in Egypt. For this reason, soil samples were collected from four fields to determine radium equivalent activity $\left(\mathrm{Ra}_{\mathrm{eq}}\right)$, absorbed dose rate (D), annual effective dose rate (AEDE), external hazard $\left(\mathrm{H}_{\mathrm{ex}}\right)$, internal hazard $\left(\mathrm{H}_{\mathrm{in}}\right)$ and Gamma radiation representative level Index (I $\gamma)$ for workers in these fields.

\section{Experimental Work}

Sample collection

TENORM contaminated soil samples were collected from different oil fields in Egypt (1) Onshore production oilfield at the western bank of Suez Gulf, near to Hurghada city, about 400 kilometers from Cairo (Field1), (2) West Desert production oilfield at the middle of western desert about 455 kilometers from Cairo (Field2), (3) Production oilfield at Cairo - Oasis road near to $6^{\text {th }}$ of October city about 80 kilometer from Cairo (Field3). (4) Onshore production oilfield at the western bank of the Suez Gulf, near to Ras Ghareb city about 300 kilometers from Cairo (Field4). Figure (1) shows fields location.

\section{Samples preparation}

The collected samples were preserved on plastic bags to prevent cross-contamination and transferred to Lab for radiometric investigations. In order to obtain a representative sample, the collected NORM contaminated soil samples were air-dried at $(25-30 \circ \mathrm{C})$ for two weeks, after that they were heated in an oven at $105{ }^{\circ} \mathrm{C}$ for $24 \mathrm{~h}$. Then, the soil samples were screened to remove stones and pebbles. Finally, they were crushed, sieved through a $0.2 \mathrm{~mm}$ mesh sieve.

An accurate $100 \mathrm{~cm}^{3}$ of the each sample were packed in a PVC cylindrical radon-tight Marinelli beaker (volume: $100 \mathrm{~cm}^{3}$ ), sealed tightly by sealing tape for preventing radon escape and stored for four weeks before the radiometric measurements (allowing establishment of secular equilibrium between radium and its decay products).

\section{Radiometric analysis}

The samples were $\gamma$-assayed to determine the activity for radioactivity $\left({ }^{226} \mathrm{Ra},{ }^{232} \mathrm{Th}\right.$, and $\left.{ }^{40} \mathrm{~K}\right)$ using high-resolution HPGe spectrometry system with relative photo peak efficiency of $40 \%$. The resolution of this spectrometer was $1.95 \mathrm{keV}$ at $1332 \mathrm{keV} \gamma$-rays of ${ }^{60} \mathrm{Co}$ and operated with Canberra Genie 2000 software for gamma acquisition and analysis.

After measurement and subtraction of the background, the activity concentrations were calculated as follows:

a) ${ }^{226} \mathrm{Ra}$ activity was determined by measuring the $295.1(19.2 \%)$ and $352(37.1 \%) \mathrm{keV} \gamma$-rays from ${ }^{214} \mathrm{~Pb}$ and 609.3 (46.1\%) and $1120.3(15 \%) \mathrm{keV} \gamma$ rays from ${ }^{214} \mathrm{Bi}$. The ${ }^{226} \mathrm{Ra}$ concentration was calculated by averaging over the measured activity for ${ }^{214} \mathrm{~Pb}$ and ${ }^{214} \mathrm{Bi}$.

b) ${ }^{232} \mathrm{Th}$ activity was determined from the $\gamma$-peaks of $238.6(44.6 \%) \mathrm{keV}$ from ${ }^{212} \mathrm{~Pb}$ and $338.4(12 \%)$, and $\quad 583.0(30 \%) \mathrm{keV} \gamma$-rays from ${ }^{208} \mathrm{Tl}$.

c) ${ }^{40} \mathrm{~K}$ activity was determined from its 1460 $(10.7 \%) \mathrm{keV} \gamma$-line.

The counting time was about $60,000 \mathrm{~s}$ to obtain a g-spectrum of good statistics. 


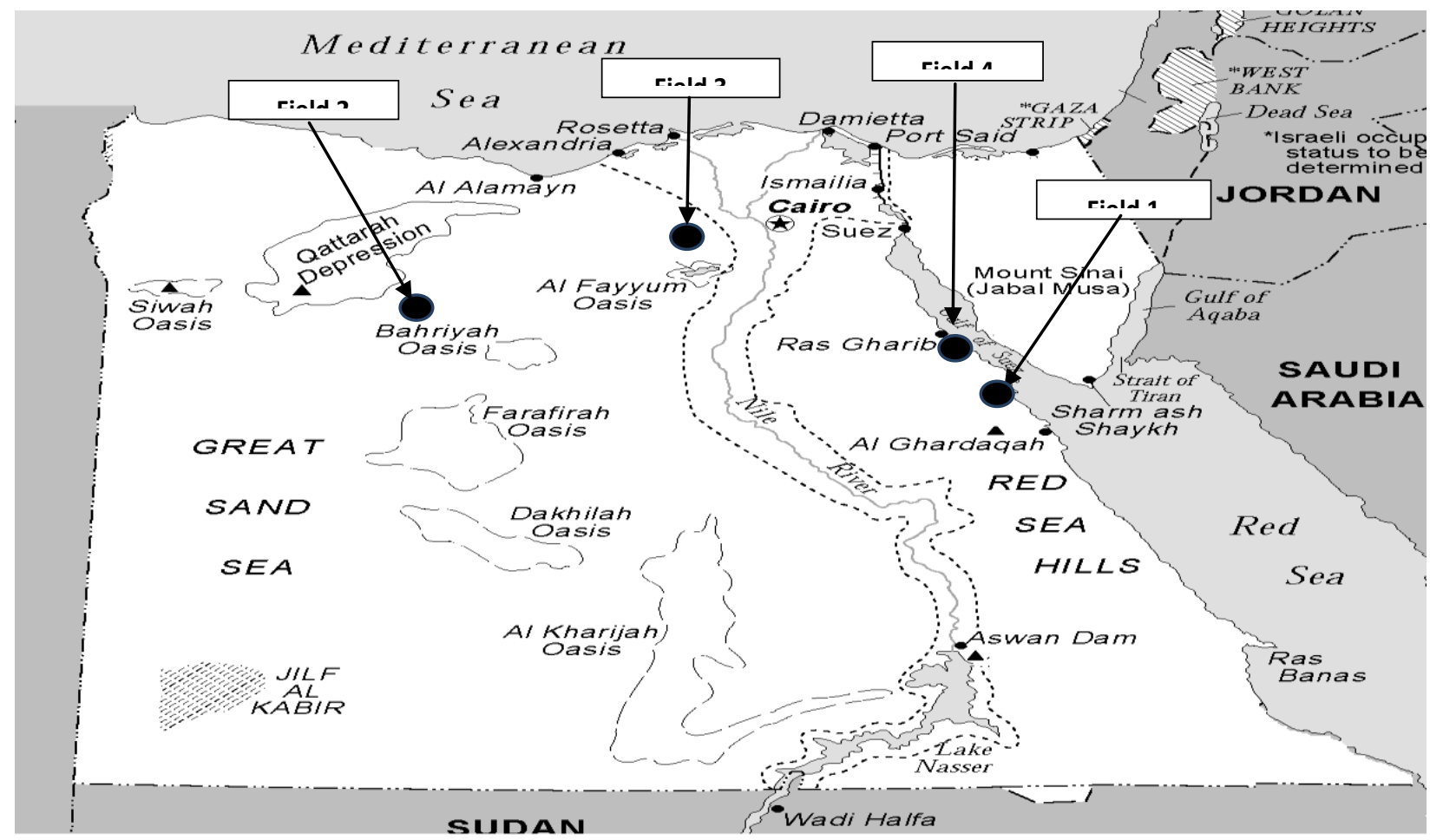

Figure (1): Fields location

\section{Calculations of radiological effect}

\section{Absorbed dose rate}

In order to assess radiological risk, the external exposure to radiation arising from naturally occurring radionuclides can be determined in terms of the absorbed dose rate. The absorbed dose rate in air at 1 meter above the ground surface has a direct relationship with the activity concentrations of natural radionuclides ${ }^{238} \mathrm{U},{ }^{232} \mathrm{Th}$ and ${ }^{40} \mathrm{~K}$. The contribution of terrestrial gamma radiation to the absorbed doses in air were calculated using the following formula [11-12]:

$\mathrm{D}\left(\mathrm{nGy} \mathrm{h}^{-1}\right)=0.462 \mathrm{~A}_{\mathrm{U}}+0.604 \mathrm{~A}_{\mathrm{Th}}+0.042 \mathrm{~A}_{\mathrm{K}}$

Where:

$\mathrm{D}$ is the absorbed dose rate in $\mathrm{nGy} \mathrm{h}^{-1}$,

$\mathrm{A}_{\mathrm{U}}, \mathrm{A}_{\mathrm{Th}}$ and $\mathrm{A}_{\mathrm{K}}$ are the activity concentrations of ${ }^{238} \mathrm{U},{ }^{232} \mathrm{Th}$ and ${ }^{40} \mathrm{~K}$ in $\mathrm{Bq} \mathrm{kg}^{-1}$ respectively.

\section{Annual effective dose equivalent (AEDE)}

The annual effective dose equivalent from outdoor gamma radiation can estimated by taking into account the conversion coefficient from the absorbed dose in air to the effective dose and the outdoor occupancy factor.
A values of $0.7 \mathrm{~Sv} \mathrm{~Gy}^{-1}$ can be used for the conversion coefficient from the absorbed dose in air to the effective dose received by adults, 0.2 is the outdoor occupancy factor proposed by the UNSCEAR depending on the living style of the workers which represents about 8 hours out of 24 hours of the working day (considering that the working days is about half year days). The annual effective dose equivalent $\left(\mathrm{mSv} \mathrm{y}^{-1}\right)$ was determined as follows [1]:

$\operatorname{AEDE}\left(\mathrm{mSv} \mathrm{y}^{-1}\right)=\mathrm{D}\left(\mathrm{nGy} \mathrm{h}^{-1}\right) \times 8760 \times \mathrm{O} \times \mathrm{C} \times$ $10^{-6}\left(\mathrm{mSv} \mathrm{nGy}^{-1}\right)$

Where

- D is the absorbed dose rate in $\mathrm{nGy} \mathrm{h}^{-1}$,

- O is the occupancy factor,

- $\quad$ C is the conversion coefficient and,

- 8760 are hours in a year.

\section{Radiation hazarded indices}

Radium equivalent radioactivity (Raeq)

Radium equivalent radioactivity $\left(\mathrm{Ra}_{\mathrm{eq}}\right)$ was calculated using the following equation [1]:

$\mathrm{Ra}_{\mathrm{eq}}=\mathrm{A}_{\mathrm{Ra}}+1.43 \mathrm{~A}_{\mathrm{Th}}+0.077 \mathrm{~A}_{\mathrm{K}}$ 
where: $\mathrm{A}_{\mathrm{Ra}}, \mathrm{A}_{\mathrm{Th}}$ and $\mathrm{A}_{\mathrm{K}}$ are the activity concentration of ${ }^{226} \mathrm{Ra},{ }^{232} \mathrm{Th}$ and ${ }^{40} \mathrm{~K}$ in $\mathrm{Bq} / \mathrm{kg}$, respectively.

\section{Gamma radiation level index (I $\gamma)$ :}

The gamma index (I $\gamma$ ) was calculated using the following equation as proposed by the European commission [13]:

$I \gamma=\left(A_{U} / 300+A_{T h} / 200+A_{K} / 3000\right)$

where, $A_{U}, A_{T h}$ and $A_{K}$ are the activity concentration of ${ }^{238} \mathrm{U},{ }^{232} \mathrm{Th}$, and ${ }^{40} \mathrm{~K}$ in $\mathrm{Bq} / \mathrm{kg}$, respectively.

The external hazard index $\left(H_{e x}\right)$ :

The external hazard index $\left(\mathrm{H}_{\mathrm{ex}}\right)$ was calculated using the following formula:

$\mathrm{H}_{\mathrm{ex}}=\left(\mathrm{A}_{\mathrm{Ra}} / 370+\mathrm{A}_{\mathrm{Th}} / 259+\mathrm{A}_{\mathrm{K}} / 4810\right) \leq 1(5)$

Where $A_{R a}, A_{T h}$ and $A_{K}$ are the specific activities of ${ }^{226} \mathrm{Ra},{ }^{232} \mathrm{Th}$ and ${ }^{40} \mathrm{~K}$ in $\mathrm{Bq} / \mathrm{kg}$, respectively [14].

The internal hazard index $\left(H_{\text {in }}\right)$ :

The internal hazard index $\left(\mathrm{H}_{\text {in }}\right)$ was calculated using the following formula:

$\mathrm{H}_{\text {in }}=\left(\mathrm{A}_{\mathrm{Ra}} / 185+\mathrm{A}_{\mathrm{Th}} / 259+\mathrm{A}_{\mathrm{K}} / 4810\right) \leq 1(6)$

where $A_{R a}, A_{T h}$ and $A_{K}$ are the specific activities of ${ }^{226} \mathrm{Ra},{ }^{232} \mathrm{Th}$ and ${ }^{40} \mathrm{~K}$ in $\mathrm{Bq} / \mathrm{kg}$, respectively [14].

\section{Results and Discussion}

The radiometric properties of the contaminated soils are illustrated in Table (1). From these data, it is clear that the specific activity has remarkable differences from site to site depending on the formation of crude oil reservoir.

The average activity concentrations of ${ }^{238} \mathrm{U}$ were found to be 42567, 10539, 6939 and $166 \mathrm{~Bq} / \mathrm{Kg}$ for Fields 1, 2, 3 and 4 respectively. The average activity concentrations of ${ }^{232} \mathrm{Th}$ were found to be 8358, 2246, 2297 and 88 Bq/Kg for Fields 1, 2, 3 and 4 respectively. The average activity concentrations of ${ }^{40} \mathrm{~K}$ were found to be 440,132 , 114 and $52.22 \mathrm{~Bq} / \mathrm{Kg}$ for Fields $1,2,3$ and 4 respectively.

The Levels of activity concentrations of $U$ and $T h$ series of the contaminated soil samples differ from field to field depending on the source rocks of the oil reservoirs and consequently the associated produced water that discharged into the soil. Although the fields 1 and 4 are in adjacent area (Suez Gulf), they exhibited different activities.

\section{Absorbed dose rate}

The results of the absorbed dose rate were calculated and given in Table (2). The average calculated absorbed dose rate ranged from 132.39 - $24732.67(\mathrm{nGy} / \mathrm{h})$ depending on the activity concentration of NORM contamination. The highest value of the absorbed dose rate was at the Field (1) (24736.97 nGy/h) that had the highest NORM activity concentration, the lowest calculated absorbed dose rate was at Field (4) $(132.39 \mathrm{nGy} / \mathrm{h})$ that had the lowest NORM activity concentration.

\section{Annual effective dose equivalent (AEDE)}

The annual effective dose equivalent values were calculated and listed in Table (2)._The highest value of the calculated Annual Effective Dose Equivalent at the Field (1) was $30.36 \mathrm{mSv} / \mathrm{y}$ with the highest NORM activity concentration, while the lowest the calculated Annual Effective Dose Equivalent at Field ( 4) was $0.16 \mathrm{mSv} / \mathrm{y}$ with the lowest NORM activity concentration.

The average Annual Effective Dose Equivalent for Fields (1,2 and 3) ranged from $5.64-30.33$ $\mathrm{mSv} / \mathrm{y}$ (depending on the activity concentration of NORM contamination) which is higher than the corresponding worldwide values of $0.50 \mathrm{mSv} / \mathrm{y}$ [1, 15]. On the other hand, the Annual Effective Dose Equivalent for Fields (4) is less than the corresponding worldwide values.

Figure (2) presents the relation between the activity concentrations of the NORM contamination and the annual external effective dose equivalent to workers.

The values of workers annual external effective dose in NORM contaminated areas in oil and gas production sites shows that the external dose depends on the activity concentrations of NORM contamination (The higher the activity, the higher the annual external effective dose equivalent). 
Table (1): Radiometric properties of the selected contaminated soils

\begin{tabular}{ccccc}
\hline \multirow{2}{*}{ Site } & Sample & \multicolumn{3}{c}{ specific radioactivity $(\mathrm{Bq} / \mathrm{Kg})$} \\
& No. & Ra-226 & Th-232 & K-40 \\
\hline \multirow{5}{*}{ Field1 } & 1 & $42486 \pm 810$ & $8369 \pm 334$ & $444 \pm 3.1$ \\
& 2 & $42627 \pm 816$ & $8356 \pm 332$ & $435 \pm 2.9$ \\
& 3 & $42588 \pm 813$ & $8349 \pm 331$ & $441 \pm 3.0$ \\
& Average & $42567 \pm 813$ & $8358 \pm 332$ & $440 \pm 3.0$ \\
\cline { 2 - 5 } Field2 & 1 & $10527 \pm 210$ & $2220 \pm 89$ & $140 \pm 1.1$ \\
& 2 & $10549 \pm 212$ & $2265 \pm 92$ & $121 \pm 0.9$ \\
& 3 & $10535 \pm 211$ & $2253 \pm 91$ & $135 \pm 1.0$ \\
& Average & $10539 \pm 211$ & $2246 \pm 91$ & $132 \pm 1.0$ \\
\cline { 2 - 5 } Field3 & 1 & $6932 \pm 151$ & $2302 \pm 92$ & $119 \pm 0.8$ \\
& 2 & $6945 \pm 153$ & $2292 \pm 90$ & $110 \pm 0.65$ \\
& 3 & $6940 \pm 150$ & $2297 \pm 91$ & $113 \pm 0.72$ \\
& Average & $6939 \pm 151$ & $2297 \pm 91$ & $114 \pm 0.72$ \\
\cline { 2 - 5 } Field4 & 1 & $166 \pm 3$ & $91 \pm 3.6$ & $52.40 \pm 0.37$ \\
& 2 & $165 \pm 2.9$ & $87 \pm 3.5$ & $53.82 \pm .38$ \\
& 3 & $168 \pm 3.1$ & $87 \pm 3.5$ & $50.45 \pm 0.36$ \\
& Average & $166 \pm 3$ & $88 \pm 3.5$ & $52.22 \pm 0.37$ \\
\hline & & & &
\end{tabular}

The values of workers annual external effective dose in NORM contaminated areas in oil and gas production sites shows that the external dose depends on the activity concentrations of NORM contamination (The higher the activity, the higher the annual external effective dose equivalent).

\section{Radiation hazarded indices}

The natural activity concentration of NORM contamination in oil and gas production sites is usually resulted from ${ }^{226} \mathrm{Ra},{ }^{232} \mathrm{Th}$ and ${ }^{40} \mathrm{~K}$ contents. As $98.5 \%$ of the radiological hazards of ${ }^{238} \mathrm{U}$ series was produced from ${ }^{226} \mathrm{Ra}$ and its daughter products, the contribution from the $238 \mathrm{U}$ has been replaced with the decay product ${ }^{226} \mathrm{Ra}$. The gamma ray radiation hazards due to the specified radionuclides were assessed by different indices [16-17].

\section{Radium equivalent radioactivity $\left(R a_{e q}\right)$}

Radium equivalent radioactivity $\left(\mathrm{Ra}_{\mathrm{eq}}\right)$ is the first index that has been introduced to represent the specific activities of ${ }^{226} \mathrm{Ra},{ }^{232} \mathrm{Th}$ and ${ }^{40} \mathrm{~K}$ by a single quantity, which takes into account the health hazard effects produced from the activity concentrations of ${ }^{238} \mathrm{U},{ }^{232} \mathrm{Th}$, and ${ }^{40} \mathrm{~K}$ radionuclides in soil [18-19]. The $\mathrm{Ra}_{\mathrm{eq}}$ is related to the external gamma dose and internal dose due to radon and its daughters. The maximum value of $\mathrm{Ra}_{\mathrm{eq}}$ in natural radioactivity must be less than 370 $\mathrm{Bq} / \mathrm{kg}$ for safe use $[11,20]$.

The values of the Radium equivalent radioactivity $\left(\mathrm{Ra}_{\mathrm{eq}}\right)$ were calculated and listed in Table (3). From the data obtained, the radium equivalent activities for fields (1,2 and 3) ranged from 10232 $\mathrm{Bq} / \mathrm{kg}$ to $54609 \mathrm{~Bq} / \mathrm{kg}$ with average of 26181 $\mathrm{Bq} / \mathrm{kg}$ that is higher than the assigned international allowed limits $(370 \mathrm{~Bq} / \mathrm{kg})$ for safe handling use [1]. However, the Radium equivalent radioactivity $\left(\mathrm{Ra}_{\mathrm{eq}}\right)$ for field (4) was within the assigned international allowed limits. 
Table (2): Absorbed dose rate $\&$ annual effective dose equivalent

\begin{tabular}{|c|c|c|c|c|c|c|}
\hline \multirow{2}{*}{ Site } & \multirow{2}{*}{$\begin{array}{c}\text { Sample } \\
\text { No. }\end{array}$} & \multicolumn{3}{|c|}{ Specific radioactivity $(\mathrm{Bq} / \mathrm{Kg})$} & \multirow{2}{*}{$\begin{array}{l}\text { Absorbed } \\
\text { Dose Rate } \\
\text { D (nGy/h) }\end{array}$} & \multirow{2}{*}{$\begin{array}{c}\text { Annual } \\
\text { Effective Dose } \\
\text { Equivalent } \\
\text { mSv/y }\end{array}$} \\
\hline & & ${ }^{238} \mathrm{U}$ & ${ }^{232} \mathrm{Th}$ & ${ }^{40} \mathrm{~K}$ & & \\
\hline \multirow{4}{*}{ Field1 } & 1 & $42486 \pm 810$ & $8369 \pm 334$ & $444 \pm 3.1$ & 24702.06 & 30.29 \\
\hline & 2 & $42627 \pm 816$ & $8356 \pm 332$ & $435 \pm 2.9$ & 24758.97 & 30.36 \\
\hline & 3 & $42588 \pm 813$ & $8349 \pm 331$ & $441 \pm 3.0$ & 24736.97 & 30.34 \\
\hline & Average & $42567 \pm 813$ & $8358 \pm 332$ & $440 \pm 3.0$ & 24732.67 & 30.33 \\
\hline \multirow{4}{*}{ Field2 } & 1 & $10527 \pm 210$ & $2220 \pm 89$ & $140 \pm 1.1$ & 6210.23 & 7.62 \\
\hline & 2 & $10549 \pm 212$ & $2265 \pm 92$ & $121 \pm 0.9$ & 6246.78 & 7.66 \\
\hline & 3 & $10535 \pm 211$ & $2253 \pm 91$ & $135 \pm 1.0$ & 6233.65 & 7.64 \\
\hline & Average & $10539 \pm 211$ & $2246 \pm 91$ & $132 \pm 1.0$ & 6231.15 & 7.64 \\
\hline \multirow{4}{*}{ Field3 } & 1 & $6932 \pm 151$ & $2302 \pm 92$ & $119 \pm 0.8$ & 4597.99 & 5.64 \\
\hline & 2 & $6945 \pm 153$ & $2292 \pm 90$ & $110 \pm 0.65$ & 4597.58 & 5.64 \\
\hline & 3 & $6940 \pm 150$ & $2297 \pm 91$ & $113 \pm 0.72$ & 4598.41 & 5.64 \\
\hline & Average & $6939 \pm 151$ & $2297 \pm 91$ & $114 \pm 0.72$ & 4597.99 & 5.64 \\
\hline \multirow{4}{*}{ Field4 } & 1 & $166 \pm 3$ & $91 \pm 3.6$ & $52.40 \pm 0.37$ & 133.86 & 0.16 \\
\hline & 2 & $165 \pm 2.9$ & $87 \pm 3.5$ & $53.82 \pm .38$ & 131.04 & 0.16 \\
\hline & 3 & $168 \pm 3.1$ & $87 \pm 3.5$ & $50.45 \pm 0.36$ & 132.28 & 0.16 \\
\hline & Average & $166 \pm 3$ & $88 \pm 3.5$ & $52.22 \pm 0.37$ & 132.39 & 0.16 \\
\hline
\end{tabular}

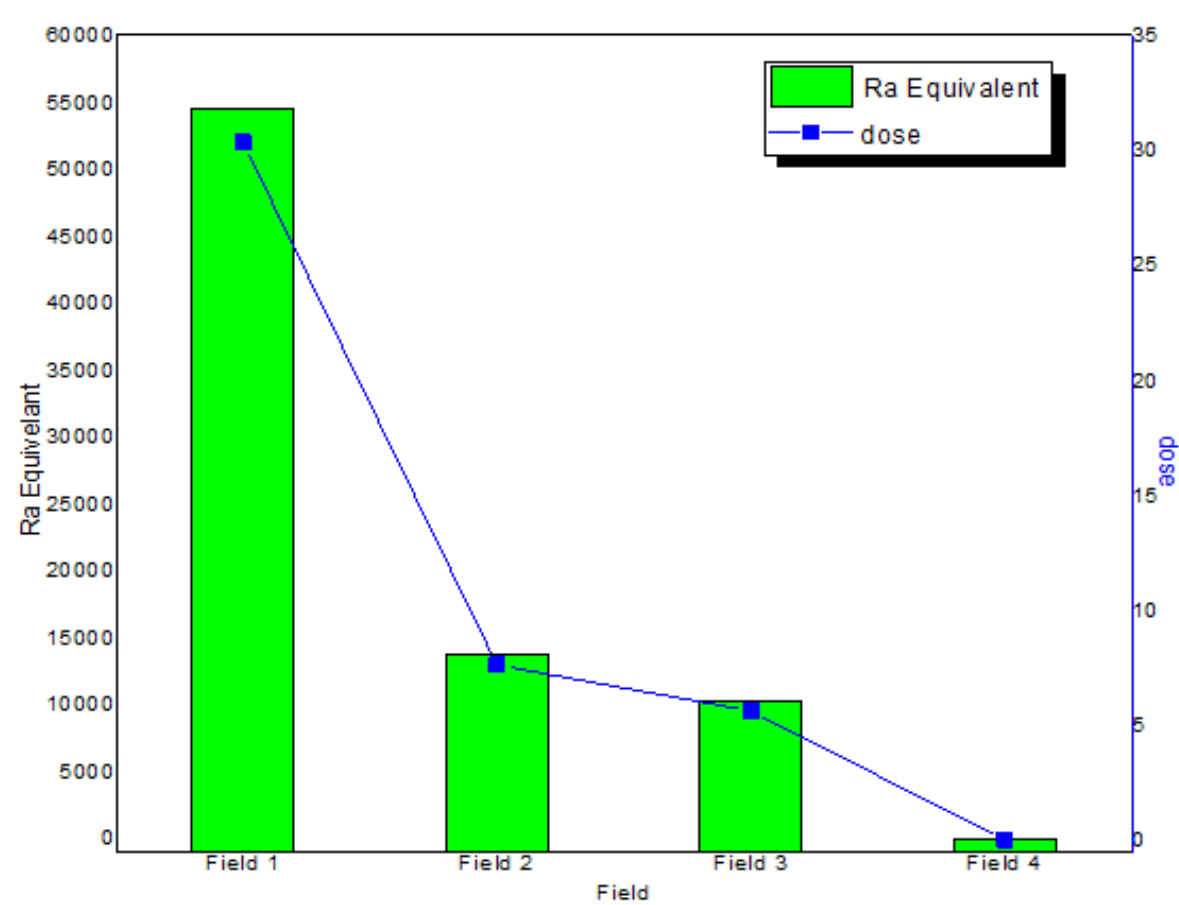

Figure (2): Activity concentrations of the NORM Contamination and annual external effective dose equivalent of workers 
Table (3): Radiation hazarded indices

\begin{tabular}{|c|c|c|c|c|c|}
\hline Site & $\begin{array}{l}\text { Sample } \\
\text { No. }\end{array}$ & $\begin{array}{l}\text { Radium } \\
\text { Equivalent } \\
\mathrm{Ra}_{\mathrm{eq}}(\mathrm{Bq} / \mathrm{Kg})\end{array}$ & $\begin{array}{l}\text { Gamma } \\
\text { Index } \\
\text { I } \gamma\end{array}$ & $\begin{array}{l}\text { Internal } \\
\text { Hazard } \\
\text { Index } \\
\mathrm{H}_{\text {in }}\end{array}$ & $\begin{array}{l}\text { External } \\
\text { Hazard } \\
\text { Index } \\
\mathrm{H}_{\mathrm{ex}}\end{array}$ \\
\hline \multirow{4}{*}{ Field1 } & 1 & $54487.86 \pm 910$ & 183.61 & 262.06 & 147.23 \\
\hline & 2 & $54609.58 \pm 920$ & 184.02 & 262.77 & 147.56 \\
\hline & 3 & $54561.03 \pm 915$ & 183.85 & 262.53 & 147.43 \\
\hline & Average & $54552.82 \pm 915$ & 183.83 & 262.45 & 147.41 \\
\hline \multirow{4}{*}{ Field2 } & 1 & $13712.38 \pm 228$ & 46.24 & 65.50 & 37.05 \\
\hline & 2 & $13797.27 \pm 236$ & 46.53 & 65.79 & 37.28 \\
\hline & 3 & $13767.19 \pm 230$ & 46.43 & 65.67 & 37.20 \\
\hline & Average & $13760.94 \pm 231$ & 46.40 & 65.67 & 37.18 \\
\hline \multirow{4}{*}{ Field3 } & 1 & $10233.02 \pm 180$ & 34.66 & 46.38 & 27.65 \\
\hline & 2 & $10231.03 \pm 179$ & 34.65 & 46.41 & 27.64 \\
\hline & 3 & $10233.41 \pm 180$ & 34.66 & 46.41 & 27.65 \\
\hline & Average & $10232.49 \pm 179$ & 34.65 & 46.40 & 27.65 \\
\hline \multirow{4}{*}{ Field4 } & 1 & $300.16 \pm 5$ & 1.03 & 1.26 & 0.81 \\
\hline & 2 & $293.55 \pm 4.8$ & 1.00 & 1.24 & 0.79 \\
\hline & 3 & $296.29 \pm 4.9$ & 1.01 & 1.25 & 0.80 \\
\hline & Average & $296.66 \pm 4.9$ & 1.01 & 1.25 & 0.80 \\
\hline
\end{tabular}

Gamma radiation level index (I $\gamma)$

The gamma radiation level index (I $\gamma)$ is suggested by the European Commission to assess the hazardous level of radionuclides in the human body when exposed to an amount of external annual effective doses of $\gamma$ radiations decayed from radioactive nuclides in soils. This index is very important for quality control of $\gamma$ radiation annual effective doses and in monitoring radiation inside human body to ensure that such radiation does not exceed the worldwide permissible high dose values [19].

The exemption dose criterion $(0.3 \mathrm{mSv} / \mathrm{y})$ corresponds to $\mathrm{I} \gamma \leq 0.5$, whereas the dose criterion $1 \mathrm{mSv} / \mathrm{y}$ corresponds to $\mathrm{I} \gamma \leq 1$ [13]. On other hand, for superficial and other materials, the corresponding values of $\mathrm{I} \gamma$ should be between 2 and 6.

The results of the gamma index (I $\gamma$ ) were calculated and shown in Table (3). From the data 
obtained, the gamma index (I $\gamma$ ) for fields (1, 2 and 3) ranged from 34.65 to 184.02 which is much higher than the assigned values proposed by European Commission for safe handling use, while the gamma index (I $\gamma)$ for field (4) was 1.01 which is within the assigned values.

The external and internal hazard index $\left(H_{e x}, H_{i n}\right)$ The external hazard index can obtained from radium expression. This index value must be less than unity in order to keep the radiation hazard insignificant; i.e. the radiation exposure due to the radioactivity from NORM is limited to $1.0 \mathrm{mSv} / \mathrm{y}$ [14]. On other hand, the internal hazard index $\left(\mathrm{H}_{\mathrm{in}}\right)$ gives the internal exposure to carcinogenic radon and its short-lived daughter.

The results of the external and internal hazard indexes were calculated and shown in Table (3). From the data obtained, the external hazard index $\left(\mathrm{H}_{\mathrm{ex}}\right)$ for fields $(1,2$ and 3) ranged from 27.65 to 147.57 with average 70.75 that is much higher than the international values $\left(\mathrm{H}_{\mathrm{ex}}<1\right)$, while the external hazard index $\left(\mathrm{H}_{\mathrm{ex}}\right)$ for field $(4)$ was 0.8 which is within the international values.

The internal hazard index $\left(\mathrm{H}_{\text {in }}\right)$ for fields $(1,2$ and 3) ranged from 46.40 to 262.77 with average 124.94 that is much higher than the international values $\left(H_{\text {in }}<1\right)$, while the internal hazard index $\left(\mathrm{H}_{\text {in }}\right)$ for field (4) was 1.25 which is considered within the international values.

From the above data, it is clear that the absorbed dose rate, annual effective dose equivalent and the radiation hazard indices of fields $(1,2 \& 3)$ are much higher than those in field (4). This depends on the activity concentrations of NORM contamination generated from the discharged produced water (The highest the activity, the highest the absorbed dose rate, annual effective dose equivalent and the radiation hazard indices).

\section{Conclusions}

Based on these data, monitoring of the workers of the production companies with high NORM contamination is highly recommended. Contamination area restriction and a job rotation of workers is very important, also the time spent in the areas of contamination has to be minimized as much as they can according to ALARA principles. In addition, the Egyptian regulations must be coherent to force companies to decontaminate the NORM contamination in order to reduce as much as possible the radiation exposure of workers.

\section{References}

1-UNSCEAR, 2000. United Nations Scientific Committee on the Effects of Atomic Radiation, Sources and effects of ionizing radiation, Report to General Assembly, with Scientific Annexes, 2000. United Nations, New York, 265 - 273.

2-Bou-Rabee, F., Al-Zamel, A., Al-Fares,R. (2009). Technologically Enhanced Naturally Occurring Radioactive Materials in the Oil Industry (TENORM) A review. NUKLEONIKA, 54(1), 3-9.

3-Egidi P., Hull C., 1999. NORM and TENORM: procedures, users, and proposed regulations, in: Health Physics Society, 32nd Midyear topical Meeting Albuquerque, New Mexico, USA, January 24-27, 1999, pp. 25-30.

4-El Afifi E.M., Hilal M.A., Khalifa S.M., Aly H.F. (2006). Evaluation of $\mathrm{U}, \mathrm{Th}, \mathrm{K}$ and emanated radon in some NORM and TENORM samples. Radiation Measurements, 41, $627-633$.

5-El Afifi E.M., Awwad N.S., Hilal M.A., (2009). Sequential chemical treatment of radium species in TENORM waste sludge produced from oil and natural gas production. Journal of Hazardous Materials, 161, 907-912

6-IAEA, 1994. International Atomic Energy Agency (IAEA), International basic safety standards for the protection against ionizing radiation and for the safety of radiation sources. GOV/2715/Vienna.

7-Steinhäusler F., 1980, Assessment of the radiation burden to man from the technologically enhanced natural radioactive environment. Turkish Atomic Energy Commission J 7:55-66.

8-Al-Masri, M.S., 2006. Spatial and monthly variations of radium isotopes in produced water during oil production. Appl. Radiat. Isot. 64, 615-623.

9-IAEA, 2004. Radiation protection and the management of radioactive waste in the oil and gas industry. In: Safety Reports Series, vol. 34. IAEA, Vienna.

10-Al Attar, L., Safia, B., 2013. Sorption of 226Ra from oil effluents onto synthetic cation exchangers. Journal of Environmental Management 124, 156-164.

11-Beretka, J. and Mathew, P.J., 1985. Natural radioactivity of Australian building materials. Industrial wastes and by-products, Health Physics., 48, 87-96.

12-Ajekiigbe1, K.M., Yinusa1, S.T., Olise, F.S. Gbenu, S.T. Arowojolu, M.I., Adeojo1, S.A., Olaniyi1J. H.B., 2017. Gamma Spectrometric Analysis of Soil, Sediment and Water Samples of Granitic Type Solid Mineral Mining Activities J. Rad. Nucl. Appl. 2, No. 1, 17-21. 
13-EC (European Commission), 1999 Radiological protection principles concerning the natural radioactivity of building materials, Radiation protection, 112.

14-Hilal, M. A., Attallah, M. F., Gehan, Y. M., \& Fayez-Hassan, M., 2014. Evaluation of radiation hazard potential of TENORM waste from oil and natural gas production. Journal of Environmental Radioactivity, 136, 121-126.

15-ICRP, 2007. The 2007 Recommendations of the International Commission on Radiological Protection. ICRP Publication 103.

16-NEA-OECD, 1979. Nuclear Energy Agency. Exposure to Radiation from Natural Radioactivity in Building Materials. Report by NEA Group of Experts. OECD, Paris.

17-El-Taher, A., Makhluf, S., Nossair, A., Abdel Halim, A.S., 2010. Assessment of natural radioactivity levels and radiation hazards due to cement industry. Applied Radiation and Isotopes 68, 169-174.

18-Alharbi W, AlZahrani J, Abbady A. 2011, Assessment of radiation hazard indices from granite rocks of the South-Eastern Arabian Shield, Kingdom of Saudi Arabia. Austr J Basic Appl Sci; 5: 672-682.

19-ABU SAMREH M., THABAYNEH K., KHRAIS F., 2014, Measurement of activity concentration levels of radionuclides in soil samples collected from Bethlehem Province, West Bank, Palestine. Turkish J Eng Env Sci. 38: 113-125.

20-Taqi, A. H., Al-Ani L. A., Ali A. M., 2016. Assessment of the natural radioactivity levels in Kirkuk oil field, Journal of Radiation Research and Applied Sciences 9, Issue 3, 337-344. 